\title{
Identification of a new phomoxanthone antibiotic from Phomopsis longicolla and its antimicrobial correlation with other metabolites during fermentation
}

\author{
Jung Nam Choi ${ }^{1}$, Jiyoung Kim ${ }^{1}$, Kannan Ponnusamy ${ }^{1}$, Chaesung Lim $^{1}$, Jeong Gu Kim², Maria John Muthaiya ${ }^{1}$ \\ and Choong Hwan Lee ${ }^{1}$
}

The Journal of Antibiotics (2013) 66, 231-233; doi:10.1038/ja.2012.105; published online 5 December 2012

Keywords: antimicrobial activity; metabolite profiling; NMR spectroscopy; Phomopsis longicolla; Xanthomonas oryzae

Agricultural production incurs substantial losses mainly due to plant diseases all over the world every year. Rice, the most important crop, provides food for over half of the world's human population, but many bacterial and fungal diseases affect rice plants, reducing the yield. ${ }^{1}$ Bacterial leaf blight (BLB) in particular is a major rice disease from an economic point of view in irrigated and rain-fed lowland ecosystems. ${ }^{2}$ Xanthomonas oryzae pv. oryzae (Xoo), a member of the gammaproteobacteria, is a major pathogen causing BLB of rice. Xoo enters rice leaves through water pores or wounds and moves systemically by invading the xylem, causing the disease known as bacterial blight. ${ }^{3,4}$ The last decade has seen a dramatic advancement in our understanding of the molecular basis of the rice/Xoo interaction with research on rice resistance and many virulence-related genes. ${ }^{5-8}$

In previous research, we reported the antimicrobial activity of secondary metabolites from Phomopsis longicolla S1B4 against Xoo and other pathogenic microorganisms. ${ }^{9}$ Phomopsis are endophytic fungi that are rich sources of secondary metabolites including phomopsins, hexapeptides containing many unnatural amino acids (P. leptostromiformis), phomopsolides, $\alpha, \beta$-unsaturated $\delta$-lactones $(P$. oblonga), dicerandrols, xanthone dimers ( $P$. longicolla), phomodiol, phomopsichalasin, phomoxanthones, phomopsidin, phomol, mycoepoxydienes, phomoenamide and phomonitroester (Phomopsis sp.). ${ }^{10-12}$ However, the optimal fermentation time for maximal antibacterial activity of $P$. longicolla S1B4 against Xoo has not yet been identified. Also, only a few investigations have been carried out to identify new bioactive compounds from P. longicolla.

In the present study, multivariate statistical analysis was employed to identify metabolites that had significantly changed as a function of antimicrobial activity against Xoo during $P$. longicolla S1B4 fermentation. In addition, the new antimicrobial secondary metabolite monodeacetylphomoxanthon B was detected in P. longicolla S1B4, the structure of which was identified by NMR spectroscopy.
The endophytic fungus $P$. longicolla S1B4 was isolated from a plant sample collected in Hadong-gun Kyungnam province, South Korea. Seed cultures of $P$. longicolla S1B4 were maintained on potato dextrose agar plates for 5 days at $25^{\circ} \mathrm{C}$. To prepare the seed culture, plugs of agar supporting mycelial growth were cut and transferred into $200 \mathrm{ml}$ liquid medium and incubated at $25^{\circ} \mathrm{C}$ on a rotary shaker for 3 days at 150 r.p.m. Afterwards, to investigate metabolite changes according to fermentation time, the seed culture was inoculated into $200 \mathrm{ml}$ liquid medium, and incubated at $25^{\circ} \mathrm{C}$ at 150 r.p.m. for 20 days. ${ }^{11,13}$ All the fermented samples were collected at 2-day intervals and the experiments were carried out in triplicate.

Identification of molecular mass and secondary metabolite profiling were performed on an ACQUITY UPLC (Waters Corporation, Milford, MA, USA) with a Q-Tof Premier mass spectrometer detector (Waters) in a range between 100 and $1500 \mathrm{Da}$ under negative ionization conditions, with argon as the collision gas. Individual secondary metabolite extracts according to fermentation time were prepared from ethyl acetate extracts of $80 \%$ aqueous acetone extracts of mycelia. Secondary metabolite profiling data sets obtained by UPLC-Q-Tof-MS were preprocessed via peaking and alignment before multivariate statistical analysis, using a combination of software to maximize information regarding metabolite differences. Raw data sets were exported using the Databridge application manager in Masslynx (version 4.1; Waters) to the NetCDF file ( $\left.{ }^{*} . \mathrm{cdf}\right)$ format and processed using the freeware $\mathrm{R}$ package XCMS to generate metabolite sheets comprising $\mathrm{m} / \mathrm{z}$, retention time and peak intensity (peak area) values for each variable in every sample. Multivariate statistical analysis was performed using SIMCA-P + software (version 12.0; Umetrics, Umeå, Sweden) with $\log _{10}$ transformation and unit variance scaling. On the basis of this analysis the metabolites contributing maximal antibacterial activity of $P$. longicolla S1B4 against Xoo has been identified.

${ }^{1}$ Department of Bioscience and Biotechnology, Konkuk University, Seoul, Republic of Korea and ${ }^{2}$ Genomics Division, National Academy of Agricultural Science (NAAS), Rural Development Administration (RDA), Suwon, Korea

Correspondence: Professor CH Lee, Department of Bioscience and Biotechnology, Konkuk University, 1 Hwayang-dong, Gwangjin-gu, Seoul 143-701, Korea

E-mail: chlee123@konkuk.ac.kr

Received 17 April 2012; revised 5 September 2012; accepted 23 October 2012; published online 5 December 2012 
Table 1 The most significantly different secondary metabolites identified by UPLC-Q-Tof-MS according to fermentation time in P. longicolla S1B4

\begin{tabular}{|c|c|c|c|c|c|c|}
\hline No. & $R t^{a}(\min )$ & Measured mass $(\mathrm{m} / \mathrm{z})$ & Mass accuracy (p.p.m.) & Molecular formula & Tentative identification & P-value $(<0.01)$ \\
\hline 1 & 4.01 & 637.0991 & & & $\mathrm{NI}$ & 0.0000 \\
\hline 2 & 4.99 & 331.0746 & & & $\mathrm{NI}$ & 0.0000 \\
\hline 3 & 5.43 & 347.0485 & & & $\mathrm{NI}$ & 0.0000 \\
\hline 4 & 6.26 & 623.1730 & & & $\mathrm{NI}$ & 0.0000 \\
\hline 5 & 6.93 & 536.2863 & & & $\mathrm{NI}$ & 0.0000 \\
\hline 6 & 7.56 & 665.1885 & 2.2 & $\mathrm{C}_{34} \mathrm{H}_{34} \mathrm{O}_{14}$ & Dicerandrol A & 0.0000 \\
\hline 7 & 8.62 & 665.1839 & -4.6 & $\mathrm{C}_{34} \mathrm{H}_{34} \mathrm{O}_{14}$ & Deacetylphomoxanthone B & 0.0000 \\
\hline 8 & 9.06 & 707.1995 & 2.8 & $\mathrm{C}_{36} \mathrm{H}_{36} \mathrm{O}_{15}$ & Dicerandrol B & 0.0000 \\
\hline 9 & 9.37 & 707.1989 & 2.0 & $\mathrm{C}_{36} \mathrm{H}_{36} \mathrm{O}_{15}$ & Compound 1 & 0.0000 \\
\hline 10 & 9.78 & 749.2108 & 3.6 & $\mathrm{C}_{38} \mathrm{H}_{37} \mathrm{O}_{16}$ & Dicerandrol C & 0.0000 \\
\hline 11 & 10.02 & 657.4247 & 3.0 & $\mathrm{C}_{36} \mathrm{H}_{58} \mathrm{~N}_{4} \mathrm{O}_{7}$ & Fusaristatin A & 0.0000 \\
\hline 12 & 10.24 & 502.2969 & & & $\mathrm{NI}$ & 0.0000 \\
\hline 13 & 10.76 & 534.3229 & & & $\mathrm{NI}$ & 0.0000 \\
\hline
\end{tabular}

aRetention time.

bevel of significance.

As mentioned above, the mycelium that was filtered from 101 volume of $P$. longicolla S1B4 fermentation broth was extracted with 11 of aqueous acetone (80\%) and then filtered. The extract was concentrated in vacuo to yield about $200 \mathrm{ml}$, which was then subjected twice to solvent partitioning with an equal volume of ethyl acetate. The extracts appeared as black sirup (20 g) upon concentration and loaded onto a Sephadex LH-20 column $(120 \times 3.3 \mathrm{~cm}$ i.d. $)$ in a solution that contained a methanol:distilled water ratio of 8.0:2.0. Ten millilitre fractions were collected separately, and the final purification of compound $\mathbf{1}$ was accomplished via HPLC (YMC pack-pro $\mathrm{C}_{18}$ column, $250 \times 4.6 \mathrm{~mm}$ ) using an isocratic aqueous acetonitrile solvent system. Each purified compound was dissolved in $\mathrm{CD}_{3} \mathrm{CN}\left(\mathrm{CD}_{3} \mathrm{CN}\right.$; Sigma-Aldrich, St Louis, MO, USA) and analyzed by $1 \mathrm{D}$ NMR $\left({ }^{1} \mathrm{H}\right.$ $(600 \mathrm{MHz})$ and ${ }^{13} \mathrm{C}(150 \mathrm{MHz}) \mathrm{NMR}$, Varian Unity-600, CA, USA) and 2D NMR (HMBC, Varian Unity-600, CA, USA) techniques.

On the basis of the multivariate analysis, 13 significantly changed secondary metabolites according to fermentation time were selected using variable importance in the projection $(>1.0)$ and their $P$-value statistics $(P<0.01)$ (Table 1$)$. The summarized most important metabolites were identified using an in-house database and comparison with published literature. ${ }^{11,12}$ Dicerandrol A, B and C, deacetylphomoxanthone $\mathrm{B}$, fusaristatin $\mathrm{A}$ and several non-identified metabolites including compound $\mathbf{1}$ were detected as significantly different secondary metabolites according to fermentation time.

In addition, compound $\mathbf{1}$ was purified and identified as previously described. The molecular formula was determined to be $\mathrm{C}_{36} \mathrm{H}_{36} \mathrm{O}_{15}$ by Q-Tof-MS data at $m / z$ 707.1989, indicating an [M-H] ${ }^{-}$(Table 1). The UV absorption spectrum was similar to that of deacetylphomoxanthone B. The ${ }^{13} \mathrm{C}$ NMR spectrum (Table 2) showed 34 carbon resonances for 36 carbons and the ${ }^{1} \mathrm{H}$ NMR spectrum presented two sets of proton resonances for two different tetrahydroxanthones. ${ }^{3} \mathrm{~J}$ HMBC correlations of H-3 $\left(\boldsymbol{\delta}_{\mathrm{H}} 7.18\right) / \mathrm{C}-4^{\prime}\left(\boldsymbol{\delta}_{\mathrm{C}} 118.3\right)$ and $\mathrm{H}-3^{\prime}\left(\boldsymbol{\delta}_{\mathrm{H}}\right.$ 7.33)/C-2 ( $\left.\boldsymbol{\delta}_{\mathrm{C}} 118.5\right)$ (Table 2) established a C-2-C-4' linkage between two tetrahydroxanthones. In addition, ${ }^{1} \mathrm{H}$ and ${ }^{13} \mathrm{C}$ NMR spectroscopic data were similar except $\mathrm{H}_{\mathrm{a}, \mathrm{b}}-12^{\prime}$ in 2 was downshifted with respect to that in phomoxanthone $\mathrm{B}$. This result indicates that the substituent at C-12' in 2 is an acetoxy group. The signal for the methyl proton of the acetoxy group, on $\mathrm{C}-15^{\prime}$, was detected at $\boldsymbol{\delta}_{\mathrm{H}}$ 1.74 , and $\mathrm{C}-15^{\prime}$ and $16^{\prime}$ signals were detected at $\boldsymbol{\delta}_{\mathrm{C}} 170.9$ and 20.8, respectively. Therefore, 2 was assigned as a new unsymmetrical tetrahydroxanthone dimer, which is the mono-deacetyl derivative of
Table $2{ }^{1} \mathrm{H},{ }^{13} \mathrm{C}$ NMR and selected HMBC data for compound 1

\begin{tabular}{|c|c|c|c|c|}
\hline Position & ${ }^{1} H(\delta)$ & ${ }^{13} \mathrm{C}(\delta)$ & & $H M B C$ \\
\hline $1-\mathrm{OH}$ & & 161 & C & \\
\hline 2 & & 118.5 & C & \\
\hline 3 & $7.18 \mathrm{~d}(8.5)$ & 140.8 & $\mathrm{CH}$ & $\mathrm{C}-1, \mathrm{C}-4 \mathrm{a}, \mathrm{C}-4^{\prime}$ \\
\hline 4 & $6.38 \mathrm{~d}(8.5)$ & 108.8 & $\mathrm{CH}$ & C-2, C-4a, C-9a \\
\hline $4 a$ & & 158.9 & C & \\
\hline 5 & $5.63 \mathrm{~d}(1.0)$ & 72 & $\mathrm{CH}$ & C-7, C-8a, C-10a, C-13 \\
\hline 6 & $2.35 \mathrm{~m}$ & 28.6 & $\mathrm{CH}$ & C-5, C-11 \\
\hline 7 & $\begin{array}{l}\mathrm{a}: 2.35 \mathrm{~m} \\
\mathrm{~b}: 2.35 \mathrm{~m}\end{array}$ & 34.3 & $\mathrm{CH}_{2}$ & $C-5, C-6, C-8$ \\
\hline $8-\mathrm{OH}$ & & 177.3 & C & \\
\hline $8 a$ & & 100.2 & C & \\
\hline 9 & & 188.2 & $\mathrm{C}$ & \\
\hline $9 a$ & & 106.3 & $\mathrm{C}$ & \\
\hline $10 a$ & & 84 & $\mathrm{C}$ & \\
\hline 11 & $0.93 \mathrm{dd}(3.5,2.5)$ & 17.7 & $\mathrm{CH}_{3}$ & $C-5, C-6, C-7$ \\
\hline 12 & $\begin{array}{l}a: 4.42 \text { d (13.0) } \\
\text { b:3.91 d (13.0) }\end{array}$ & 65.6 & $\mathrm{CH}_{2}$ & $C-5$ \\
\hline 13 & & 171.7 & C & \\
\hline 14 & $2.04 \mathrm{~s}$ & 20.9 & $\mathrm{CH}_{3}$ & C-13 \\
\hline $1^{\prime}-\mathrm{OH}$ & & 162.8 & C & \\
\hline $2^{\prime}$ & $6.53 \mathrm{dd}(4.5,8.5)$ & 110.2 & $\mathrm{CH}$ & $C-4^{\prime}, C-9^{\prime} a$ \\
\hline $3^{\prime}$ & $7.33 \mathrm{dd}$ & 140.4 & $\mathrm{CH}$ & $\mathrm{C}-1^{\prime}, \mathrm{C}-4^{\prime} \mathrm{a}, \mathrm{C}-2$ \\
\hline $4^{\prime}$ & & 118.3 & C & \\
\hline $4^{\prime} \mathrm{a}$ & & 156 & C & \\
\hline $5^{\prime}$ & $5.33 \mathrm{~s}$ & 71 & $\mathrm{CH}$ & C-7', C-8'a, C-10'a, C-13' \\
\hline $6^{\prime}$ & $2.5 \mathrm{~m}$ & 28.8 & $\mathrm{CH}$ & $\mathrm{C}-5^{\prime}, \mathrm{C}-11^{\prime}$ \\
\hline $7^{\prime}$ & $\begin{array}{l}a: 2.35 \mathrm{~m} \\
\mathrm{~b}: 2.35 \mathrm{~m}\end{array}$ & 33.9 & $\mathrm{CH}_{2}$ & $C-6^{\prime}$ \\
\hline $8^{\prime}-\mathrm{OH}$ & & 177.7 & C & \\
\hline $8^{\prime} a$ & & 101.3 & $\mathrm{C}$ & \\
\hline $9^{\prime}$ & & 188.3 & C & \\
\hline $9^{\prime} a$ & & 107.5 & C & \\
\hline $10^{\prime} a$ & & 80.2 & $\mathrm{C}$ & \\
\hline $11^{\prime}$ & $1.01(4.5,2.0)$ & 18 & $\mathrm{CH}_{3}$ & $\mathrm{C}-5^{\prime}, \mathrm{C}-6^{\prime}, \mathrm{C}-7^{\prime}$ \\
\hline $12^{\prime}$ & $\begin{array}{l}a: 4.51 \text { d (13.0) } \\
b: 3.91 \text { d (13.0) }\end{array}$ & 65.1 & $\mathrm{CH}_{2}$ & $C-5^{\prime}, C-10 a^{\prime}, C-15^{\prime}$ \\
\hline $13^{\prime}$ & & 171.5 & C & \\
\hline $14^{\prime}$ & $2.00 \mathrm{~s}$ & 21 & $\mathrm{CH}_{3}$ & C- $13^{\prime}$ \\
\hline $15^{\prime}$ & & 170.9 & C & \\
\hline $16^{\prime}$ & $1.74 \mathrm{~s}$ & 20.8 & $\mathrm{CH}_{3}$ & C-15' \\
\hline
\end{tabular}




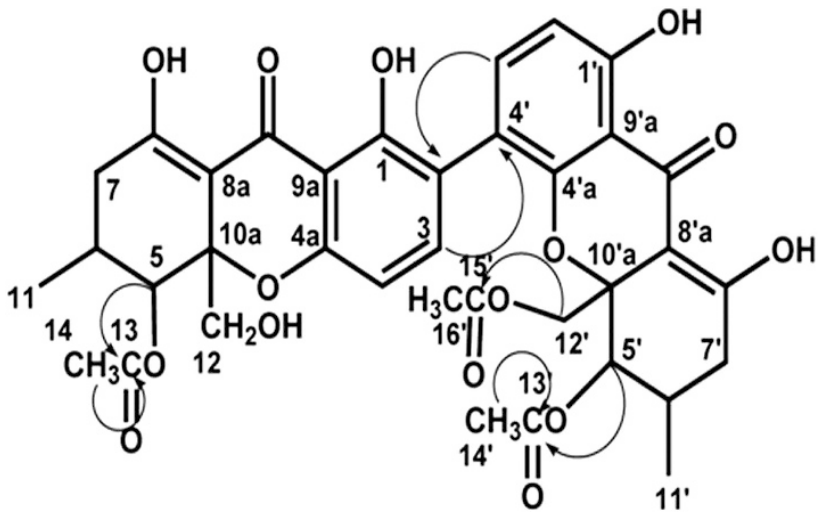

Figure $\mathbf{1}$ The structure of compound $\mathbf{1}$, monodeacettphomoxanthone $\mathbf{B}$, and its HMBC correlations.

Table 3 Antimicrobial activity against Xanthomonas oryzae of metabolites of $\boldsymbol{P}$. Iongicolla S1B4 correlated with fermentation time

\begin{tabular}{lc}
\hline Compound & $M I C\left(\mu g l^{-1}\right)$ \\
\hline Dicerandrol A & 8 \\
Deacetylphomoxanthone B & 4 \\
Dicerandrol B & 16 \\
Compound 1 (monodeacetylphomoxanthone B) & 32 \\
Dicerandrol C & $>16$ \\
DAPG & 8 \\
\hline
\end{tabular}

Abbreviation: DAPG, 2,4-diacetylphloroglucinol (positive control).

phomoxanthone B (Figure 1). ${ }^{11,14}$ In order to identify the relationships between antimicrobial activity and metabolites, the isolated new monodeacetylphomoxanthone $\mathrm{B}$ along with other identified secondary metabolites were tested by MIC values (Table 3). The maximum antimicrobial activity against xoo was registerd high with monodeacetylphomoxanthone $\mathrm{B}$ (identified by NMR) followed by dicerandrol C and dicerandrol B. 2,4-diacetylphloroglucinol served as positive control in the MIC analysis. The results indicated that the antimicrobial activity against Xoo of $P$. longicolla S1B4 is affected by the metabolites content that was tested.

This study demonstrates the changes in secondary metabolite composition in P. longicolla S1B4 as a function of fermentation and the effects of these changes on antimicrobial activity. The new compound monodeactylphomoxanthone $\mathrm{B}$, the structure of which was identified by $1 \mathrm{D}$ and 2D NMR spectroscopy, was detected as a major compound contributing functional difference in the fermentation process. This study provides valuable information regarding the optimization of the fermentation process for bioactive compound production and describes an efficient way to screen for new bioactive compounds from natural fungal sources.

\section{ACKNOWLEDGEMENTS}

This study was supported by the National Research Foundation of Korea (NRF) grant funded by the Korea government (MEST 2010-0019306, MEST 2010-0027204), and the Next Generation Biogreen21 grant funded by RDA (PJ008083), Republic of Korea.

1 Velusamy, P., Immanuel, J. E., Gnanamanickam, S. S. \& Thomashow, L. Biologica control of rice bacterial blight by plant-associated bacteria producing 2,4-diacetylphloroglucinol. Can. J. Microbiol. 52, 56-65 (2006).

2 Sana, T. R. et al. Metabolomic and transcriptomic analysis of the rice response to the bacterial blight pathogen Xanthomonas oryzae pv. oryzae. Metabolomics 6, 451-465 (2010).

3 Salzberg, S. L. et al. Genome sequence and rapid evolution of the rice pathogen Xanthomonas oryzae pv. oryzae PX099A. J. BMC Genomics 9, 204 (2008).

4 Shen, Y. \& Ronald, P. Molecular determinants of disease and resistance in interactions of Xanthomonas oryzae pv. oryzae and rice. Microbes Infect. 4, 1361-1367 (2002).

5 Yoshimura, $\mathrm{S}$. et al. Expression of Xa1, a bacterial blight-resistance gene in rice, is induced by bacterial inoculation. Proc. Natl Acad. Sci. USA 95, 1663-1668 (1998).

6 Bai, H., Li, L. Y. \& Liu, G. Z. Advances of rice bacterial blight disease resistance gene Xa21. Yi Chuan 28, 745-753 (2006).

7 Shen, Y., Sharma, P., da Silva, F. G. \& Ronald, P. The Xanthomonas oryzae pv. lozengeoryzae raxP and $\operatorname{rax} Q$ genes encode an ATP sulphurylase and adenosine- $5^{\prime}$ phosphosulphate kinase that are required for AvrXa21 avirulence activity. Mol. Microbiol. 44, 37-48 (2002).

8 Ray, S. K., Rajeshwari, R. \& Sonti, R. V. Mutants of Xanthomonas oryzae pv. oryzae deficient in general secretory pathway are virulence deficient and unable to secrete xylanase. Mol. Plant Microbe Interact. 13, 394-401 (2000).

9 Lim, C. et al. Identification, fermentation, and bioactivity against Xanthomonas oryzae of antimicrobial metabolites isolated from Phomopsis longicolla S1B4. J. Microbiol. Biotechnol. 20, 494-500 (2010).

10 Bunyapaiboonsri, T., Yoiprommarat, S., Srikitikulchai, P., Srichomthong, K. \& Lumyong, S. Oblongolides from the endophytic fungus Phomopsis sp. BCC 9789. J. Nat. Prod. 73, 55-59 (2010).

11 Rukachaisirikul, V., Sommart, U., Phongpaichit, S., Sakayaroj, J. \& Kirtikara, K. Metabolites from the endophytic fungus Phomopsis sp. PSU-D15. Phytochemistry 69, 783-787 (2008).

12 Wagenaar, M. M. \& Clardy, J. Dicerandrols, new antibiotic and cytotoxic dimers produced by the fungus Phomopsis longicolla isolated from an endangered mint. J. Nat. Prod. 64, 1006-1009 (2001).

13 Cui, C. B. et al. Acetophthalidin, a novel inhibitor of mammalian cell cycle, produced by a fungus isolated from a sea sediment. J. Antibiot. 49, 216-219 (1996).

14 Isaka, M. et al. Phomoxanthones A and B, novel xanthone dimers from the endophytic fungus Phomopsis species. J. Nat. Prod. 64, 1015-1018 (2001). 